\title{
8th German Conference on Chemoinformatics
}

\author{
Uli Fechner \\ From 8th German Conference on Chemoinformatics: 26 CIC-Workshop \\ Goslar, Germany. 11-13 November 2012
}

The 8th German Conference on Chemoinformatics (GCC2012) was held from the $11^{\text {th }}$ to the $13^{\text {th }}$ of November 2012 in Goslar, Germany and addressed a broad range of current research topics in the realm of computers and chemistry. The CIC division of the Gernan Chemical Society (GDCh) [1] invited the chemoinformatics and molecular modelling community to the GCC2012 to discuss trends and recent developments in the fields of

- Chemoinformatics and Drug Discovery

- Chemical Information, Patents and Databases

- Molecular Modelling

- Computational Materials Science and Nanotechnology

As always, researchers from other research areas of Computational Chemistry were also encouraged to submit con- tributions. The Scientific Advisory Board compiled an interesting program that consisted of 22 lectures and 53 poster presentations. More than 130 scientists from 20 nations attended the GCC 2012. The large number of attendees from countries other than Germany demonstrates that the conference is an internationally wellestablished event in the global Chemoinformatics and Modelling community. Traditionally, the conference was opened by the "Free-Software-Session". This session provided room for presentations of as well as discussions about Open-Source software and attracted an audience of both developers and users.

Two different awards were bestowed for excellent scientific work at the GCC2012. Dr. Engelbert Zass from the ETH Zurich, Switzerland was presented with the Gmelin-Beilstein-Denkmünze [2] award for his plethora of contributions to numerous chemical informtation systems and databases over the past decades. Furthermore,

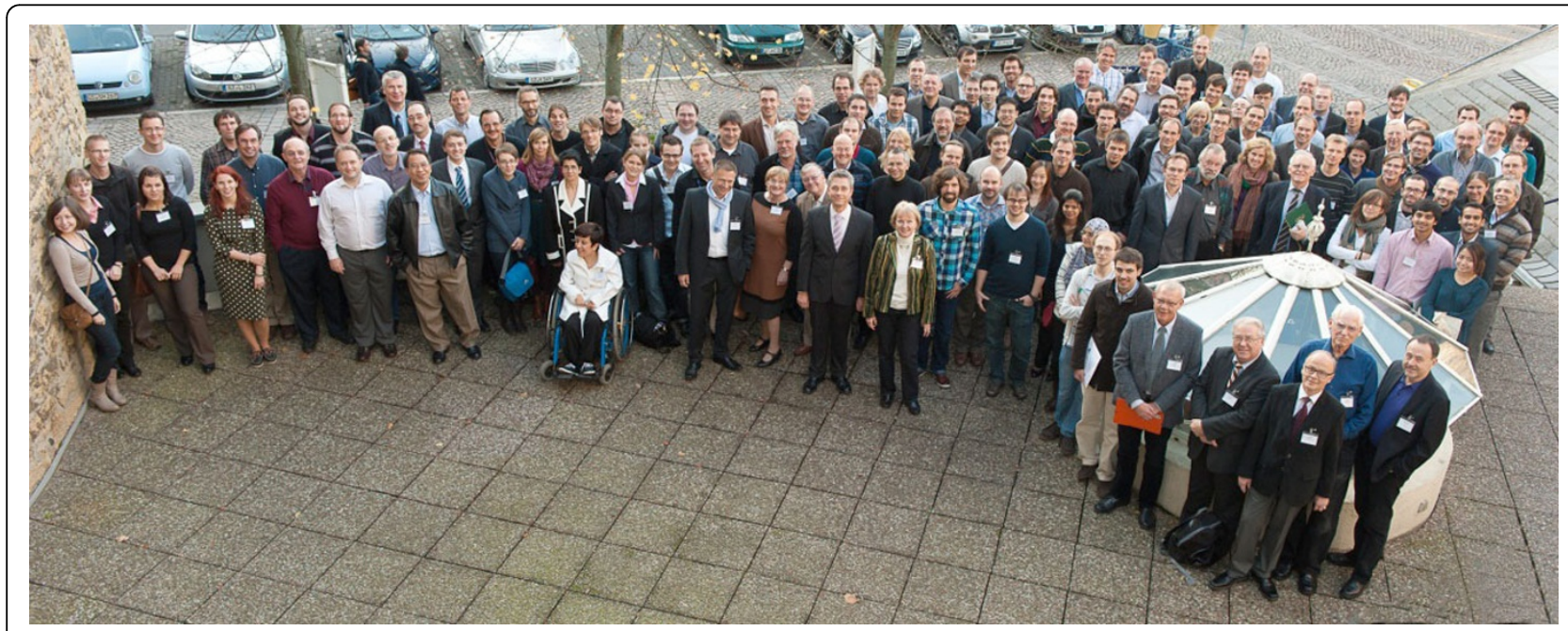

Figure 1 Participants of the 8th German Conference on Chemoinformatics (GCC2012), November 11-13, 2012 in Goslar, Germany.

Correspondence: ufechner@beilstein-institut.de

GDCh-CIC Division Board Member, Beilstein-Institut zur Förderung der

Chemischen Wissenschaften, Trakehner Str. 7-9, 60487 Frankfurt, Germany 


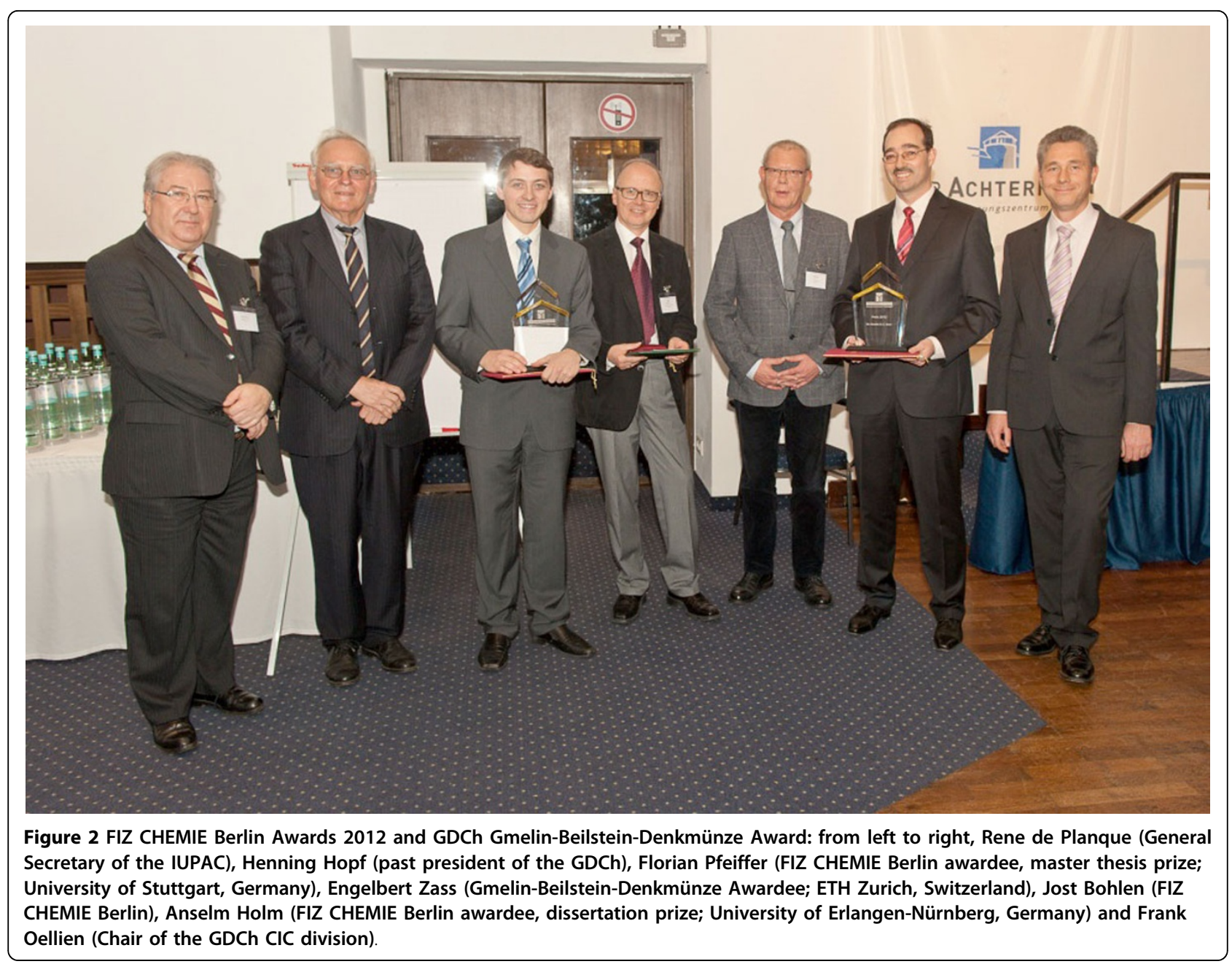

the FIZ-CHEMIE-Berlin prizes for the best $\mathrm{PhD}$ thesis and the best diploma thesis in the field of Computational Chemistry were awarded to Dr. Anselm Horn from the University of Erlangen-Nürnberg, Germany and Florian Pfeiffer from the University of Stuttgart, Germany, respectively.

Published: 22 March 2013

\section{References}

1. GDCh CIC Division: [http://www.gdch.de/cic].

2. GDCh Gmelin-Beilstein-Denkmünze: [http://www.gdch.de/gdch/preise-undauszeichnungen/gdch-preise.html].

Publish with ChemistryCentral and every
scientist can read your work free of charge
"Open access provides opportunities to our
colleagues in other parts of the globe, by allowing
anyone to view the content free of charge."
W. Jeffery Hurst, The Hershey Company.
- available free of charge to the entire scientific community
- peer reviewed and published immediately upon acceptance
- cited in PubMed and archived on PubMed Central
- yours - you keep the copyright
Submit your manuscript here:
http://www.chemistrycentral.com/manuscript/

